\title{
OS LIMITES DA DISPOSIÇÃO DO PRÓPRIO CORPO EM PESQUISAS EM HUMANOS NA PERSPECTIVA DA BIOÉTICA
}

\author{
Gustavo Silveira Borges ${ }^{1}$ \\ Mariana Mazuco Carlessi ${ }^{2}$
}

\section{RESUMO}

$\mathrm{O}$ presente artigo analisa a proteção ética em relação às pesquisas envolvendo seres humanos. Trata desde o surgimento das questões relativas ao desenvolvimento dos estudos médicos e evolução das tecnologias aplicadas até os dias atuais, considerando a Bioética e o Biodireito. Traz a discussão ética sobre a possibilidade de o pesquisador aplicar em si substancia capaz de alterar seu DNA, questionando o princípio da autonomia e as justificativas necessárias para realização de uma pesquisa em seres humanos. Para tanto, utiliza-se o método de abordagem hipotético dedutivo mediante pesquisa bibliográfica e normas nacionais e internacionais.

PALAVRAS-CHAVE: Direitos Humanos; Novos Direitos; Bioética; Pesquisa em Humanos; Limites Normativos.

\section{THE LIMITS OF THE DISPOSITION OF THE OWN BODY IN HUMAN RESEARCH IN THE PERSPECTIVE OF BIOETHICS}

ABSTRACT This article analyzes the ethical protection in relation to research involving human beings. It deals with the emergence of issues related to the development of medical studies and evolution of technologies applied to the present day, considering bioethics and biorights. It brings the ethical discussion about the possibility of the researcher applying in itself substance capable of altering its DNA, questioning the principle of autonomy and the necessary justifications for conducting research on human beings. For this, the method of deductive hypothetical approach is used through bibliographical research and national and international standards.

KEYWORDS: Human Rights; New Rights; Bioethics; Research on Human Beings; Normative Limits

\section{INTRODUÇÃO}

\footnotetext{
${ }^{1}$ Pós-Doutor em Direito pela UNISINOS. Doutor em Direito na UFRGS. Professor do Curso de Direito da Universidade do Extremo Sul Catarinense (UNESC). Endereço postal: Rua Giovani Luiz Piucco, 870, bairro Ferraz, Garopaba/SC - CEP 88495-000. E-mail: gustavoborges@ hotmail.com.

${ }^{2}$ Mestranda em Direitos Humanos pela UNESC. Especialista em Direito Processual Cível pela CESUSC. Advogada. Endereço postal: Rua Pedro Cechinel, nº 95, Bairro Mina Brasil, Criciúma/S. E-mail: mmc31895@gmail.com
} 
O ser humano, em razão das características de racionalidade e curiosidade, vive em busca de identificar, criar, pesquisar e aprimorar seus conhecimentos desde os tempos mais remotos ${ }^{3}$. A busca desenfreada pelo novo, por intermédio de pesquisas realizadas em humanos, gerou, em tempos passados, como durante da Segunda Guerra Mundial, nos campos de concentração judeu, muito massacre à dignidade da pessoa humana dos pesquisados. Isso não quer dizer que a pesquisa para viabilizar o crescimento cientifico e estudos na área da Medicina deva ser obstado. Ao contrário disso, é esse o ponto que a Bioética se propõe a discutir sobre o assunto: realizar as pesquisas, porém sem se abster da eticidade.

Antes das normativas ${ }^{4}$ que atualmente regem as pesquisas realizadas em seres humanos, essas eram justificadas pelos próprios pesquisadores e sua aprovação se dava desde que a pesquisa fizesse o "bem" para sociedade, sem observar a real necessidade de sua aplicação (ANDRADE, 2006, p. 136). Contudo, com o passar do tempo, orientações e normas jurídicas de todos os cunhos foram surgindo, o que gerou a necessidade de incluir nos debates envolvendo as pesquisas com seres humanos o teor regido pelos princípios éticos, desde a formação, desenvolvimento até conclusão.

Daí então, diversos documentos projetaram sinais e princípios e apresentaram normatizações com pretensões universais para ofertar alternativas de resolução dos conflitos éticos, tal como a Declaração Universal sobre Bioética e Direitos Humanos de 2006, de forma que pesquisas realizadas em seres humanos obedecessem uma série de critérios desde seu início até sua conclusão, aproximando o Direito e a Medicina, mesmo que a segunda, na maioria das vezes, evolua cientificamente com mais rapidez que a primeira, que vem posteriormente estabelecer as regras de conduta.

Assim, o presente estudo tem por objetivo analisar como se deve aplicar os princípios Bioéticos na questão da disposição do próprio corpo, onde o pesquisado e o pesquisador são o mesmo indivíduo, e realizar experimentos não mais no próximo, mas em si mesmo, deixando dúvidas com relação à eticidade em volta da evolução médicocientífica (ARAÚJO, 2003).

\footnotetext{
3 “Desde tempos imemoriais experimentam-se tratamentos novos em pacientes que apresentam sintomas incomuns ou não respondem aos tratamentos convencionais. A mais antiga coleção de leis que se tem notícia - o Código de Hamurabi - já estabelecia prêmios para os cirurgiões que obtivessem êxito em suas experiências e castigos para aqueles que errassem". (VIEIRA, HOSSNE, p. 2, 1997)

${ }^{4}$ Tais como a Declaração de Helsinki, Código de Nuremberg, Diretrizes Internacionais para Pesquisas em Seres Humanos de 1993, Resolução CNS 466/2012, entre outras.
} 
Feitas algumas considerações que remetem o atual cenário da Bioética, surgem os seguintes questionamentos que merecem transposição: como devem ser compreendidos os conceitos da Bioética a partir de sua perspectiva histórica? Quais os fatores interligam a Bioética com os Direitos Humanos? Quais as normativas jurídicas estabelecidas para a realização de pesquisa em humanos? E, por fim, existe limite para disposição do próprio corpo em pesquisa realizada por interesse do próprio pesquisador?

Consideradas as questões acima, não é por menos importante refletir e analisar sobre essa temática, já que as pesquisas nas ciências da saúde são necessárias e de muita importância, ao passo que muitas vezes não há como escapar que sejam realizadas no próprio ser humano, dependendo do seu objetivo. É a partir dessa reflexão que se discutirão alguns aspectos relativos às pesquisas e questões éticas inerentes, principalmente realizadas no corpo do próprio pesquisador.

\section{A BIOÉtiCA E OS DIREITOS HUMANOS PELA EVOLUÇÃO DA CIÊNCIA MÉDICA}

\subsection{Bioética: a história do surgimento e seu sentido atual}

A partir da modernidade, marcados pela originalidade entre os séculos XVI e XVIII (RODRIGUES, 2010, p. 31), o homem deixou de direcionar sua vida para os adventos pós morte, como ocorria na era medieval ${ }^{5}$ e passou a olhar para o presente com pretensões de progresso. Foi, então, nesse momento, que ocorreu o rompimento de paradigmas relativos à visão pós morte e gerou autonomia de liberdade do homem para pensar além dessa fronteira, de modo que, no que diz respeito à ciência, essa ficou marcada pela transição das crenças religiosas para o racionalismo, onde a verdade cientifica passou a ser "revelação da válida e incontestável verdade". (BORGES, 2017, p. 21)

Não significa dizer que na Idade Média não realizavam pesquisas, ao contrário disso, muito antes já se concretizavam pesquisas de várias espécies, tal como na era da Grécia Antiga (300 a.C), marcada por Hipócrates e Galeno, bem como na Idade Média, já se buscava saber sobre o corpo humano como objeto para entender seu funcionamento a partir do adoecer, visando a cura toda vez que fosse possível (SOUZA, 2006, p. 27). É

\footnotetext{
${ }^{5}$ Época em que possuía uma perspectiva de que o futuro não era passível de projetos, ou seja, o homem não prospectava o futuro em vida, mas somente se pensava na vida após morrer.
} 
possível dizer também de Tales, que previu o eclipse solar e calculou as pirâmides do Egito e seu sucessores como Pitágoras, Demócrito, Sócrates, Platão e por ai segue uma geração outros filósofos e pensadores (ANDRADE, 2006, p. 131). No entanto, foi somente no decorrer da Idade Moderna que as pesquisas se tornaram independente e ousadas a ponto de se desvincular de mitos religiosos e, assim seguiu, até a metade do século XX, em que as pesquisas eram realizadas sem balizas éticas concretas.

O origem da Bioética, de acordo com diversos autores da área ${ }^{6}$, se deu no período marcado pela segunda metade do século XX, entre os anos de 1960 e $1970^{7}$, em que a ciência e tecnologia biomédica, dado os estudos referentes à cura enquanto conhecimento aplicado ganharam espaço e receberam fortes incentivos tendo sido considerados os resultados de caráter prático que tais pesquisas ocasionaram (SILVA, 2016, p. 264). A preocupação ética e moral com os admissíveis emprego de novas técnicas à saúde humana, como também com as técnicas e pesquisas que já vinha sendo feitas, mesmo sem antes possuir qualquer normas legais ou controles, fez nascer, segundo Letícia Moller, que diz:

“(...) um novo campo de estudo destinado à reflexão e discussão interdisciplinar acerca de questões delicadas e complexas tais como as que envolvem o início e o fim da vida, a doença, a relação médico-paciente, a realização de pesquisas com seres humanos, a manipulação genética" (MOLLER, 2006, p. 155).

Sob esse cenário, a Bioética serve para estabelecer parâmetros, princípios e diretrizes para alinhar os objetivos e a condução da pesquisa e sua aplicação aos reais experimentos e seus consequentes resultados.

Apesar de a Bioética ganhar seus primeiros contornos reais em meados dos anos 60 e 70, no ano de 1997, um artigo publicado na Alemanha por Rolf Lother ${ }^{8}$ revelou que o termo, na verdade, foi mencionado pela primeira vez por Fritz Jahr, em 1927, contrapondose à ideia de Kant, criou o termo Bio-ethik, e disse "respeite todos os seres vivos como um fim em si mesmo e trate-os como tal, se possível", conceituando a Bioética reconhecendo obrigações éticas além do ser humano, incluindo todos os demais seres vivos. (GOLDIM 2006).

\footnotetext{
${ }^{6}$ Soares, Wolkmer, Müller e Clotet são alguns dos autores que desenvolvem teoricamente sobre o início da discussão sobre a ética nos procedimentos médicos (ENVOLVENDO A DISPOSIÇÃO DO PRÓPRIO CORPO OU NÃO? SE SIM, PODES DIZER). SOARES; PIÑEIRO, 2006, p. 14; WOLKMER, 2016, p. 263; CLOTET, 2003, p. 22-24).

${ }^{7}$ Klinger Fontinele Júnior afirma que o surgimento e evolução da Bioética se deu já a partir dos anos 50, quando a obra Princípios Científicos Aplicados na Enfermagem, em 1959. (FONTINELE JUNIOR, 2003, p. 3)

${ }^{8}$ Lother encontrou o texto que falava sobre Bioética 47 anos anos ante de Van Rensselaer Potter, porém foi Eve Marie Engel que divulgou essa informação (GOLDIM, 2006)
} 
Contudo, outros autores entendem que o termo Bioética foi ventilado pela Fundação Kennedy ${ }^{9}$, mas de fato, pronunciado pela primeira vez em 1971, por Van Rensselaer Potter, chamado de "criador da Bioética", em sua obra nomeada Bioethics: a bridge to the future, na qual conjecturou a reflexão da abrangência da relação entre os seres humanos com o futuro. Segundo Goldim (2009, p. 59), sua contribuição foi de excelente valor para discussão de temas emergentes sobre a questão da vida. Para Potter, segundo Clotet menciona (1993, p. 15) a Bioética seria a ciência que asseguraria a continuidade da vida, sendo incapaz de se separar os valores éticos dos fatos biológicos, criando assim, o neologismo. Tanto Jahr como Potter levantaram uma questão importante em relação ao futuro da humanidade: a responsabilidade de garantir o futuro da vida na terra. (PESSINI, 2013, p. 10)

Ainda no ano de 1970, nos centros de estudos The Kennedy Institute of Ethics $e$ Hastings Center, que André Hellegers ${ }^{10}$ definiu, ou seja, conceituou o termo Bioética, pela primeira vez, como sendo "o estudo sistemático das dimensões éticas - incluindo visão, decisão, conduta e normas morais - das ciências da vida e da saúde, utilizando uma variedade de metodologias éticas num contexto interdisciplinar". Esse Instituto consagrou seu entendimento sobre Bioética como sendo uma ética de fato aplicada (SOARES; PIÑEIRO, 2006, p. 14). Essa definição recebeu bastantes críticas, conforme Junges (1999, p. 21), considerando que havia, em seu conceito a palavra princípios éticos, o que excluiria outros tipos de referenciais como convicção, atitudes, virtudes e emoções. Mais tarde, a definição teve a inclusão da palavra "valores" para acentuar a abertura para todas as fontes de conhecimento moral.

Diversos outros eventos e autores abalizaram o teor da definição de Bioética, como ocorreu pelo Belmond Report, em 1978, relatório que estabeleceu as bases da utilização dos princípios da Bioética, quais sejam, autonomia, beneficência e justiça. Após o relatório de Belmond e inspirados nele, Tom Beauchamp e James Childress, ambos

\footnotetext{
${ }^{9}$ O Instituto Kennedy (Kennedy Center for the Study of Human Reproduction and Development) já funcionava antes de $1^{\circ}$ de outubro de 1971, data em que foi efetivamente inaugurado (SOARES; PIÑEIRO, 2006, P. 14). André Hellegers e Paul Ramsey. Hellegers ao lado de Fr. Henley, propôs, em 1970, à Fundação Kennedy, a criação do Kennedy Center for the Study of Human Reproduction and Development. Em 1971 o nome mudou para The Joseph and Rose Kennedy Center for the Study of Human Reproduction and Bioethics, e, finalmente, para The Kennedy Institute of Ethics. Já Paul Ramsey publicou, em 1970, portanto pouco antes de Potter, o livro The Patient as Person: Explorations in Medical Ethics, que antecipou algumas das discussões da Bioética. (OLIVEIRA, 2006, p. 1187- 1227)

${ }^{10}$ Médico obstetra e ginecologista holandês que chegou nos Estados Unidos com 27 anos e foi se tornando pesquisador notável. (SOARES; PIÑEIRO, 2006, p.14).
} 
vinculado ao Kennedy Institute of Ethic, publicaram, no mesmo ano, o clássico livro Princípios de Ética Biomédica, que ganhou força dentro e, aos poucos, fora dos Estados Unidos, estabelecendo o uso de princípios da Bioética, os chamados deveres prima face, ${ }^{11}$ os quais servem até os dias de hoje como fundamento do agir moral e da ética biomédica, para os dilemas bioéticos.

O conjunto dos quatro princípios elaborados por Beauchamp e Childress tornou-se referencial teórico e se denominou de principialismo, ou seja, a escola Bioética baseada no uso dos princípios como modelo explicativo. (GOLDIM, 2009, p. 60) São eles: princípio da autonomia e beneficência, de ordem teleológica ${ }^{12}$, e princípio da não-maleficência e justiça, de ordem deontológica ${ }^{13}$.

O princípio da autonomia ${ }^{14}$ traduz a liberdade do indivíduo, chamado também de princípio do respeito às pessoas, exige aceitar que elas se autogovernem nas suas escolhas ou por intermédio de seu representante legal, respeitando sua integridade. Requer que o médico respeite a vontade, valores morais e crenças dos pacientes, priorizando sempre suas decisões, quando essas não colocarem em risco a vida de outros. Ou seja, tem o direito de decidir autonomamente a aceitação ou rejeição do que se quer fazer com ele, tanto em relação ao diagnóstico como em relação á terapêutica.

O princípio da beneficência, fundamentado no respeito à vida física do paciente, dispõe sobre a atuação do médico, ao que torna a pessoa o objetivo principal, ou seja, a pessoa está acima dos interesses da ciência ou sociedade quando essa participa de qualquer

\footnotetext{
11 "Este conceito foi proposto por Sir David Ross, em 1930. Ele propunha que não há, nem pode haver, regras sem exceção. O dever prima facie é uma obrigação que se deve cumprir, a menos que ela entre em conflito, numa situação particular, com um outro dever de igual ou maior porte. Um dever prima facie é obrigatório, salvo quando for sobrepujado por outras obrigações morais simultâneas. Esta 'proposta já havia sido utilizada pelo Tribunal Constitucional Alemão". (GOLDIM, 2003).

${ }_{12}$ Qualquer doutrina que identifica a presença de metas, fins ou objetivos últimos guiando a natureza e a humanidade, considerando a finalidade como o princípio explicativo fundamental na organização e nas transformações de todos os seres da realidade; teleologismo, finalismo.

${ }^{13}$ Teoria moral criada pelo filósofo e jurisconsulto inglês Jeremy Bentham (1748-1832) que, rejeitando a importância de qualquer apelo ao dever e à consciência, compreende na tendência humana de perseguir o prazer e fugir da dor o fundamento da ação eticamente correta; deontologismo.

${ }^{14}$ Também denominado de princípio do respeito às pessoas ou de princípio do consentimento. Este último foi proposto por $\mathrm{H}$. Tristram Engelhardt "para indicar melhor que o que está em jogo não é algum valor possuído pela autonomia ou pela liberdade, mas o reconhecimento de que a autoridade moral secular deriva do consentimento dos envolvidos em um empreendimento comum. O princípio do consentimento coloca em destaque a circunstância de que, quando Deus não é ouvido por todos do mesmo modo (ou não é de maneira alguma ouvido por ninguém), e quando nem todos Pertencem a uma comunidade perfeitamente integrada e definida, e desde que a razão não descubra uma moralidade canônica concreta, então a autorização ou autoridade moral secularmente justificável não vem de Deus, nem da visão moral de uma comunidade particular, nem da razão, mas do consentimento dos indivíduos. Nessa surdez a Deus e no fracasso da razão os estranhos morais encontram-se como indivíduos". (ENGELHARDT, 1998. p. 17)
}

Revista de Biodireito e Direito dos Animais | e-ISSN: 2525-9695 | Salvador | v. 4 | n. 1 | p. 1 - 21 | 
procedimento médico ou de pesquisas científicas. De modo geral, esse princípio deve se preocupar com os interesses e bem-estar do paciente ou pesquisado, de forma que o médico, profissional da saúde ou pesquisador analise cuidadosamente e em particular, o caso do paciente antes de realizar determinado procedimento

O princípio da não-maleficência está relacionado diretamente com o princípio anterior uma vez que aponta para que o médico não utilize nenhum meio capaz de colocar em risco o paciente. De outra senda, obriga evitar que o profissional da saúde cause danos à pessoa, mesmo que a conduta utilizada pudesse ser apropriada, ou seja, evitar o dano intencional. Esse princípio, apesar de fazer parte do referencial teórico em relação à Bioética, não é unanime a todos os autores, não sendo citado em diversas obras que tratam sobre o assunto.

O princípio da justiça, segundo Goldim (1999, p. 61), estabelece o dever de não discriminar qualquer pessoa, podendo ser associado ao direito individual de cada pessoa em particular, de não ser discriminada. É a forma justa, universalizada e igualitária da distribuição dos bens e serviços médicos e hospitalares, essencialmente, à coletividade dos pacientes, garantindo a todos os pacientes os mesmos direitos. Engloba também a igualdade de distribuição das verbas do Estado para a saúde pesquisa.

Os princípios listados acima foram intensamente utilizados ao ponto em que se tornaram referencial teórico e base para a Bioética, sendo consagrados pela Conferência Geral da Unesco, em outubro de 2005, quando a Declaração Universal sobre Bioética e Direitos Humanos, criada pela Organização das Nações Unidas para Educação e Cultura (Unesco) e adotada por mais de oitenta países, definiu os princípios universais de Beauchamp e Childress como base em que a humanidade pode responder aos dilemas e controvérsias das questões relacionadas ao biodireito e Bioética.

Fato é que muitos autores concordam que Bioética é uma ciência que envolve vários campos do saber, quais sejam, biologia, medicina, psicologia, direito, sociologia, antropologia $^{15}$ e ciência política ${ }^{16}$, tratando-se, portanto, de uma ciência interdisciplinar cuja preocupação foco é pensar nos progressos científicos na questão da vida humana focada na ética ${ }^{17}$. Após a criação do termo Bioética, outros documentos foram

${ }^{15}$ Conforme as palavras de Fontunele (2003, p. 6).

${ }^{16}$ Segundo Oliveira (2011, p. 90).

${ }^{17}$ Para Beauchamp e Childress, ética é um termo genérico para várias formas de se entender e analisar a vida moral. Segundo Ricardo Tim Souza, ética é o fundamento da vida humana, a manutenção as sua própria origem. É a possibilidade fundante e meta-cientifica da racionalidade cientifica aquilo sem o qual a 
paralelamente escritos e ideias novas a respeito surgiram dando continuidade e evoluindo ao ponto de concluir que a Bioética e o direito são institutos incapazes de serem separados na sua totalidade. (RIVABEM, 2017, p. 283)

Assim, surge, então, o pensamento sobre a Bioética e a necessidade de imposição de limites, de modo que o Direito passou a se envolver na resolução das questões biomédicas.

\subsection{Bioética e Direitos Humanos: limites da ciência}

O sistema jurídico começou a ser destrinchado durante o racionalismo iluminista, na medida em que se passou a impor regras e sanções àqueles que descumprissem. Entretanto, foi a partir da segunda metade do século XX que Direito criou relação com as questões éticas envolvendo a medicina e as demais áreas referentes à saúde, estabelecendo vínculo com a justiça.

E a ética, nada mais é que o fundamento da própria vida, do próprio pensar humano, conforme entendimento de Clotet (2003, p. 22). A ética sempre esteve relacionada com o direito de forma muito próxima, ambos, por exemplo, clamam pela interferência estatal, por intermédio de órgãos legislativos, para tornar licita determinada conduta (SOARES, 2006, p. 64). A ética tem o objetivo melhorar a pessoa enquanto o direito visa a organizar o convívio social dentro da tutela da pessoa humana, complementando-se entre si.

A Bioética institucional ${ }^{18}$ tem por objetivo estudar as questões éticas relacionadas à medicina e área da vida humana em geral, bem como as tecnologias aplicadas, suas formações e atividades. Para tanto no decorrer dos anos e de acordo com as necessidades, foram criadas instituições essenciais, cujo papel é variado para se manifestarem sobre temas Bioéticos, tal como aprofundar a reflexão em Bioética e contribuir para a produção normativa e construção de consensos universais de sua natureza. Eventos como a Declaração Universal sobre Bioética e Direitos Humanos, em 2002, e instituições como

racionalidade cientifica, fechada em si mesma, acaba por implodir em sua totalização do poder e sentido, destruindo a tudo em seu autodestruir-se (SOUZA, 2005, p. 11).

${ }^{18}$ Uma das definições de instituição é "organismo público ou privado, estabelecido por meio de leis ou estatutos, que visa atender a uma necessidade de dada sociedade ou da comunidade mundial" e, ainda, "leis fundamentais de um país, que estabelecem seu ordenamento político". Portanto, é possível caracterizar a Bioética institucional como aquela que compreende tipos de instituições essenciais para o funcionamento e aplicação da própria Bioética. 
Comitê Internacional de Bioética (CIB), Comitê Internacional de Bioética (CIGB), ambos parte da Organização das Nações Unidas para Educação (UNESCO) e também o Departamento de Ética, Equidade, Comércio e Direitos Humanos, da Organização mundial da Saúde (OMS), foram criados não para focarem em casos específicos sem repercussão, mas na reflexão ética sobre temáticas abstratas, produzindo guidelines ou normas jurídicas. (OLIVEIRA, 2001, p. $91-91$ )

Agir com ética é ter conduta aprovada ou permitida, na medida que ela pode ser chamada e boa ou má (CLOTEL, 1999, p. 185). Rivabem (2018. p. 283) traça, apesar de compreender pontos de intersecção entre o direito e a Bioética, diferenças entre ambos os termos de modo que o direito, tem por objetivo buscar normatizar e proteger legalmente e juridicamente o ser humano, enquanto a Bioética normatiza, eticamente, temas complexos como início e fim da vida. E dessa forma, nasce o Biodireito, cujo termo faz conexão á Bioética, maneira prática ${ }^{19}$ de regulamentar limites e licitude das operações médicacientificas e tecnológicas, "não do ponto de vista das "exigências máximas" da fundação e da aplicação dos valores morais na práxis biomédica - isto é, a busca do que se "deve" fazer para atuar o "bem" - mas do ponto de vista da exigência ética "mínima" de estabelecer normas para a convivência social", assim menciona Judith Martins-Costa (2002, p. 67).

$\mathrm{O}$ autor Paulo Vicente Barreto comunga e reforça o entendimento de que o Biodireito não deve se fechar à legislação específica, muitas vezes elaboradas sem referências a princípios ou normas gerais, mas deve-se pautar dentro da categoria dos Direitos Humanos, de modo que assegure seus fundamentos racionais e legitimadores como, na ideia kantiana, de direito cosmopolita. (BARRETO, 1999, p. 390). De fato, no atual cenário pluralista e democrático é ultrapassado aceitar o direito e suas normas jurídicas rígidas oriundas do legalismo fechado, como trabalhado por Kelsen, considerando que, se assim fosse, muitos problemas advindos das tecnologias científicas não teriam soluções jurídicas. (BORGES, 2017, p. 43-44)

A partir do momento em que a questão normativa da Bioética passa sua aplicação para o todo, não mais apenas sobre um só indivíduo, mas estendendo os seus efeitos à coletividade de modo geral, atuando sobre o conjunto de seres humanos e também futuras gerações, como é o caso da alteração genética e mapeamento do genoma humano, cuja

\footnotetext{
${ }^{19}$ Prática porque, não se deve aplicar o biodireito, enquanto relacionado à ética, somente nas ações médicas tangíveis em acordos, declarações, tratados, compêndios ou leis.
} 
proporção dimensional toma espaço global, envolvendo, inclusive, órgãos internacionais como os citados acima, é prudente identificar e considerar a necessidade de incluir a Bioética e a sua regulamentação normativa dentro da categoria de Direitos Humanos (MOLLER, 2007, p. 153), principalmente pela relação que é traçada entre os princípios da Bioética e o princípio constitucional da dignidade da pessoa humana, conforme artigo $1^{\circ}$, inciso III da Constituição Federal Brasileira de 1988, uma vez que ideia principal dos princípios bioéticos e constitucional é a mesma, ou seja, que o ser humano não deve ser tratado como objeto, mas, como um fim em sim mesmo, jamais como meio.

Há aproximação entre o direito e a Bioética, além da questão constitucional, também pelo simples fato do próprio direito, assim como a Bioética, em se preocupar com a vida, desde o nascimento do indivíduo, sua filiação, valores existenciais, relações patrimoniais, direitos inerentes à pessoa, deveres, responsabilidades, morte, entre outros aspectos relacionados. Não é por menos que a autora Martins-Costa (2002, p. 67), em sua obra, diz que falar em direito é fundamentalmente falar em pessoa e em relação (das pessoas com as coisas, bens materiais e imateriais.

Diante dessa relação, é possível citar a Declaração Universal sobre Bioética e Direitos Humanos que não só interligou os estados aderentes a atuar de acordo com seu teor, como também pode ser considerada uma conformadora do biodireito mínimo universal que, ao ser editada, pressupôs valores éticos comuns com objetivo essencial de orientar os avanços científicos, desenvolvimento tecnológico e transformação social, prestando de guia aos Estados ao elaborarem regras e políticas públicas. São os princípios elencados na declaração:

"Dignidade e Direitos Humanos; autonomia e responsabilidade individual; respeito da vulnerabilidade humana e integridade pessoal. Privacidade e confidencialidade; igualdade, justiça e equidade; não discriminação e não estigmatizarão; respeito da diversidade cultural e do pluralismo; solidariedade e cooperação; responsabilidade social e saúde; aproveitamento partilhado dos benefícios; proteção das futuras gerações (em particular de sua constituição genética); proteção do meio ambiente, biosfera e biodiversidade". (MOLLER, 2017, p. 165)

Com o reconhecimento do princípio constitucional da pessoa humana, fica evidentemente claro que é inevitável falar de Bioética e esquecer a ponte existente com o direito, em especial com os Direitos Humanos, que são regras jurídicas dentro de um conjunto ético, quando se trata dos cuidados da saúde, por exemplo, da mesma forma que o 
Biodireito se conecta com os Direitos Humanos no modo de adequá-lo aos parâmetros com alcance universal, dentro do espaço do pluralismo cultural, apto a tutelar valores e direitos considerados fundamentais dentro das diferentes culturas, religiões e visões morais. (MOLLER, 2017, p. 169)

Feitas as considerações sobre o conceito acerca da Bioética e Direitos Humanos, passa-se a analisar as questões inerentes a pesquisa realizada pelo pesquisador em seu próprio corpo, princípios a serem balizados e o riscos à saúde da coletividade.

\section{AS PESQUISAS MÉDICAS EM SERES HUMANOS E OS LIMITES DE DISPOSIÇÃO DO PRÓPRIO CORPO}

\subsection{A pesquisa em humanos dentro da ética e sua possibilidade jurídica}

A pesquisa é uma atividade extremamente importante na sociedade e tão representativas que o número de profissionais dedicados a essa preocupação tem aumentado anualmente, trazendo importantes resultados e melhorias em diversas áreas do conhecimentos, em especial área da ciência médica.

Com a evolução da humanidade, pressupôs-se necessário desvendar diversos mistérios, aprimorar conhecimentos, descobrir novas condutas, repassar técnicas, tudo que motiva o desenvolvimento relativo à pesquisa. Pesquisar é produzir conhecimento que possa trazer benefícios tanto diretos como indiretos à sociedade de tal modo que o último século foi marcado por descoberta e inovações científicas sem precedentes na história, trazendo a ciência cada vez mais presente na vida quotidiana (MOLLER, 2007, p. 154). O ato de pesquisar foi inevitavelmente o fato que desenvolveu e aprimorou a ciência ${ }^{20}$, na produção de conhecimentos que só contribuíram para melhorar a qualidade de vida, gerando, diversos empasses e conflitos éticos, na medida em que tais pesquisas eram aplicadas em seres humanos.

Foi a partir de experimentos oriundos das pesquisas, em especial no que se refere às realizadas em seres humanos, que ficou evidente a necessidade de traçar limites a essa prática, sem, contudo, pará-la, até porque os avanços científicos, principalmente em relação à saúde humana, trouxeram muitos benefícios, como também um salto significativo

\footnotetext{
${ }^{20}$ Boaventura de Souza Santos, sobre o assunto, sustenta que a ciência moderna se encontra mergulhada numa profunda crise e que estamos vivemos uma fase de transição entre o paradigma da ciência moderna e um novo paradigma, ao qual denomina de pós moderna. (SANTOS, 1989, P. 24)
} 
para a qualidade de vida, em diversos quesitos, tais como alívio de dor, cura de diversas doenças, terapias, utilização de aparelhos, entre outros. Em contrapartida, as descobertas realizadas para atingir o fim objetivado em relação à expansão dos benefícios, em muitos casos, trilharam caminhos os quais os valores que a sociedade entende como fundamentais pudessem facilmente ser violados (MOLLER, 2007, p. 154), sendo inevitável o surgimento de preocupações com os aspectos éticos e legais em pesquisas, no sentido de propor princípios capazes de regimentarem a prática, trazendo à tona o pensamento que construíram o que é a Bioética de hoje.

Em que pese sua importância, com o passar do anos, as pesquisas foram realizadas de forma um tanto antiéticas do ponto de vista humanístico, tais como as pesquisas realizadas no início do século XX para descobrir, por exemplo sobre a doença chamada Beribéri $^{21}$. No mesmo século, sobre a febre amarela, os médicos Adolpho Lutz e Emilio Ribas internaram imigrantes italianos em um quarto hospitalar, praticaram atos desumanos para comprovar que a doença só era transmitida pelo mosquito. Os imigrantes não morreram, porém, foram submetidos a um tratamento desumano.

A falta de ética teve ápice no período da segunda guerra mundial, principalmente nos campos de concentração nazistas, que, com tanta desumanidade, originou a elaboração do Código de Nuremberg, em 1947, primeiro documento internacional que disciplinou a matéria, nas palavras de Tanise Zago Thomasi (2015, p. 201), com aditamentos realizados posteriormente (SILVA, 2006, p. 136-137). A finalidade desse código era julgar e punir de modo apropriado os criminosos de guerra, além de estabelecer o necessário consentimento do ser humano como absolutamente essencial à realização do experimento, bem como a obrigação do profissional da saúde na explicação dos motivos da pesquisa, forma de realização, métodos utilizados, entre outras informações que possam formar o juízo de valor do pesquisado em aceitar participar ou não da pesquisa (SAKAGUTI, 2009, p. 298).

Do mesmo modo, ficou estabelecido que as pesquisas só podem ser realizadas para o bem da sociedade, sem sofrimento ou danos desnecessários ao pesquisado. $\mathrm{Na}$ mesma senda, porém mais tarde, em 1964, foi instituída a Declaração de Helsinque, garantindo aos pacientes que não ficarão em desvantagens, tampouco serão explorados ao se submeterem a investigações clínicas.

\footnotetext{
${ }^{21}$ Doença nutricional causada pela falta de vitamina do complexo B, que causa fraqueza muscular, problemas de respiração e pulmonar.
} 
Além das duas diretrizes mencionadas acima, cabe ainda destacar as diretrizes éticas internacionais para pesquisa biomédicas envolvendo seres humanos, criada em 1982 e revisada em 1993, em Genebra, pelo Conselho para Organização Internacionais de Ciências Médicas em comum com a OMS, cujo propósito era indicar quais princípios éticos fundamentais deveriam sobrepor-se quando se tratassem de pesquisas envolvendo seres humanos e as diretrizes internacionais para revisão de estudos epidemiológicos, redigida pela mesma organização, em 1991. (SILVA, 2006, p. 153 - 154). Atualmente, as condutas éticas em experimentos são mais sutis, tais como a utilização de farmáticos com finalidade de favorecer a indústria terapêutica na parte econômica.

No Brasil diversas resoluções e diretrizes garantem que as pesquisas envolvendo seres humanos, individuais ou coletivas, de forma direta ou indireta, tenham por obrigação a guarda dos princípios éticos, tais como as resolução do Conselho Nacional de Saúde $\mathrm{n}^{\circ}$ 01/88, posteriormente substituída pela Resolução CNS nº 196/96, 251/97, 240/97, 292/99, 301/00, 340/04, 466/12 e 510/16. O Brasil ainda conta com instituição de pesquisa, comitês de ética em pesquisa (CEP), que são colegiados interdisciplinares e independentes de caráter consultivo, e comissão nacional de ética em pesquisa, cuja principal finalidade é supervisionar, criar, coordenar, opinar, avaliar projetos, desenvolver regulamentação, dentre outras funções ligadas às CEPs (BAZZANO, 2006, p. 157). Há também no Código Civil brasileiro, artigos naturalmente podem ser utilizados para embasar tudo que até o momento foi mencionado, tal como no artigo 186, que trata sobre imprudência, negligência e imperícia, e artigo 927 sobre a reparação de dano por ato ilícito.

A sociedade complexa leva muito tempo para formar juízo de valor em relação à práticas e hábitos. A exemplo disso, pode-se mencionar a questão relativa aos malefícios do do cigarro e do refrigerante, que antigamente não se conhecia os danos trazidos à saúde e, atualmente, é bem difundido, ao ponto de tornar-se o que antes era, de certa forma, normal, em algo que causa espanto aos não aderentes ao vício. (CLOTET, 2001, p. 55)

Não obstante, pode-se citar a situação do descompasso entre a vontade legal e os anseios da sociedade quando se trata da lei federal de transplante de órgãos. No primeiro momento, a lei 9.434/97, em seu artigo $4^{\circ}$ dizia que "salvo manifestação em contrário, (...) presume-se autorizada a doação de tecidos, órgãos ou partes do corpo humano, para finalidade de transplantes ou terapêutica post mortem". Entretanto, a sociedade, profissionais da saúde e parentes de doadores presumidos insurgiram-se contra a medida, 
por diversos motivos, dentre eles, por considerar atentatória à memória do falecido. Foi, então, necessário que o Poder Executivo elaborasse uma medida provisória alterando o dispositivo, dando, aos ascendentes, descendentes ou cônjuge o poder de decidir sobre o transplante.

Esses são só exemplos capazes de demonstrar o quando o direito é uma ciência que acaba ficando para trás diante das inovações e tendências biomédicas, de modo que a jurisdição em relação à Bioética deva, de fato, se embasar não somente na legislação escrita, mas também, de modo geral, em princípios éticos e morais que balizam os assuntos inerentes a embriões humanos, eutanásia, manipulação genética, clonagem e pesquisas em seres humanos (SOARES, 2006, p. 66 -67). De outra forma, não se pode aceitar que a omissão de leis comprometa o futuro da humanidade, como ressalta Maria Helena Diniz, sobre a importância de impor limites à medicina moderna "reconhecendo-se que o respeito ao ser humano em toda as suas fases evolutivas (...) só é alcançado se estiver atento à dignidade da pessoa humana”. (DINIZ, 2001, p. 18)

No caso da Bioética a solução para tratar certos conflitos certamente seria a de ponderar princípios contrapostos, submetendo às leis, sobretudo, aos ditames do princípio da dignidade da pessoa humana, o que, sem sombra de dúvidas, trará à norma impossibilidade de estabelecer qualquer desigualdade jurídica embasada em cor, raça, sexo, origem, idade ou qualquer outra forma de discriminação. A ideia é aplicável aos limites e imposições relativas à pesquisa em seres humanos, uma vez que, se seguida for, não excluirá dos seus direitos um determinado grupo por conta de sua raça, cor e afins.

A ética e o direito não podem estagnar, ao contrário, precisam orientar o processo de pesquisas cientificas e tecnológicas médica em prol da sociedade. Até hoje, as questões legais apontaram para a conduta em pesquisas realizada em outros seres humanos, por pesquisadores e não há nenhuma norma jurídica que disponha sobre pesquisas sobre o próprio corpo do pesquisador.

\subsection{Os riscos e limites de disposição do corpo em pesquisas}

Após tantos experimentos capazes de prevenir e curar doenças, a expectativa de vida do homem praticamente duplicou nos últimos dois séculos, mas, apesar dessa evolução, o homem não está satisfeito e se mantem na busca incessante da cura e 
prevenção de diversas doenças com objetivo de viver mais, tornando o ser humano, por força dessa vontade, cada vez mais, objeto de pesquisas.

A descoberta da possibilidade do DNA, engenharia genética, ${ }^{22}$ e o mapeamento genético, por meio de pesquisas realizadas em seres humanos, fez com que se tornasse possível o isolamento e clonagem de genes como terapia para o tratamento de certas doenças. Do mesmo modo, técnicas podem ser aplicada para prevenir doenças futuras em genomas que ainda não foram manifestados, mas no decorrer da vida humana, sofrerão certas modificações. Nesses casos, a engenharia genética é capaz de prever, prevenir e curar doenças, mas, não obstante, por não se saber de fato resultados, a mesma engenharia genética utilizada para o bem, pode também transformar o ser humano normal em superhumanos ou monstros, como mencionado na obra de Clotet (1999, p. 108).

As pesquisas para desvendar o genoma ${ }^{23}$ humano precisavam cuidar de algumas áreas envolvidas nas descobertas tais como, segundo Goldim:

\begin{abstract}
"Os pesquisadores que geram o novo conhecimento, a comunidade empresarial que transforma este conhecimento em produtos e a população que vai absorver e incorporar os novos conhecimentos em sua visão de mundo e suas práticas sociais, além de consumir os novos produtos". Isso quer dizer que os cientistas necessitavam estar em alerta e responder de forma responsável, prevendo, dentro do possível, as consequências morais da aplicação comercial do testes genéticos.” (GOLDIM, 2000).
\end{abstract}

Qualquer que seja a pesquisa, de acordo com todas as resoluções, diretrizes e normas já expostas no capítulo anterior, precisa, como se postura Paulo Henrique Oliveira (2006, p. 1219), contar com uma justificativa intrínseca (quando a justificativa cujos objetivos possuem ligação direta com o bem estar das pessoas observadas) ou extrínseca (aquelas que não possuem ligação direta com o bem estar dos observados, mas de terceiros) plausível para sua realização. Essa justificativa também precisa ser analisada do ponto de vista de sua legitimidade, pois, não é porque a pesquisa realizada em um ser humano com objetivo de almejar seu próprio bem estar que a torna, automaticamente,

\footnotetext{
${ }^{22}$ Segundo Goldim, engenharia genética é a modificação de seres vivos pela manipulação direta do DNA, através da inserção ou deleção de fragmentos específicos. Sua aplicação pode ser na produção de vacinas, proteínas por microorganismos, alimentos, transplantes, terapia gênica, animais transgênicos. (GOLDIM, 2002).

${ }^{23}$ Genoma é o genoma é toda a informação hereditária de um organismo que está codificada em seu DNA (ou, em alguns vírus, no RNA). "Todo ser humano tem uma identidade genética própria e, segundo a Declaração da Unesco, o genoma humano é propriedade inalienável de toda a pessoa e por sua vez um componente fundamental de toda a humanidade" (GOLDIM, 2000).
} 
legítima. E é justamente em relação à legitimidade da pesquisa que o biodireito busca se firmar dentro da Bioética.

Logo, ainda que não haja nenhum benefício ou vantagem direta ao sujeito de pesquisa, a sua participação no experimento poderá/deverá ter uma justificativa ética, a qual pode ter como núcleo a intenção solidária, dessa pessoa e do pesquisador, de promover benefícios para a ciência em geral e, consequentemente, para todos os demais seres humanos.

As normativas e resoluções que tratam sobre pesquisas em humanos, em todo tempo, promovem os experimentos como se esses só fossem aplicados por um pesquisador em um pesquisado, sem, contudo, legislar sobre pesquisas realizadas sobre o próprio corpo do pesquisador, que, embora esteja dispondo do seu próprio corpo, deve limitar seus experimentos às condições estabelecidas em lei. Entretanto, não é bem assim que ocorre, Nesse ponto, pode-se analisar a atitudes que biohackers ${ }^{24}$ vem desenvolvendo em si, injetando tecnologias capazes de alterar o DNA, como exemplo, o chamado CRISPR/Cas9, de maneira totalmente contrária ao que se espera de um experimento, quando, em um auditório de conferência e em posse de uma seringa contendo o material, aplicou o produto em seu próprio braço. O descobrimento, por si só, do CRISP/Cas9, substancia capaz de editar a genética, abre novos horizontes à pesquisa cientifica englobando problemas éticos, jurídicos e sociais que podem surgir com a aplicação em humanos e a atitude desses biohackers aponta justamente para essa preocupação sobre os riscos e o dilema ético das técnicas relativas à alteração do genoma humano.

O CRISP/Cas9, conforme os autores Marcela Corso Arend, Jessica Olivaes Pereira e Melissa Medeiros Markoski, é possibilita a edição do genoma por meio de ciclagem do DNA:

(...) por uma endonuclease (Cas9), guiada a partir de uma sequência de RNA, que é capaz de se parear com as bases de uma sequência-alvo. A estrutura genética do CRISPR, no sistema bacteriano (...). Desta forma, o sistema pode ser utilizado tanto para reparar mutações (restaurando a função gênica) quanto para introduzir mutações novas (causando o "nocaute" gênico). Assim, conciliando sofisticadas técnicas moleculares e biotecnológicas, o sistema CRISPR/Cas9 foi proposto para aplicação em edição genômica e hoje já se encontra comercialmente disponível para milhares de alvos. Ambos, RNA guia e proteína

\footnotetext{
${ }^{24}$ Hacker é o que se dedica, com intensidade incomum, a conhecer e modificar os aspectos mais internos de dispositivos, programas e redes de computadores. Biohacker, por sua vez, é um indivíduo que tem como prática hackear a própria biologia com o objetivo de melhorar sua performance e desempenho físico e mental.
} 
Cas9, produzidos in vitro, podem ser entregues às células usando diferentes mecanismos, tais como uso de vetores ou agentes químicos. $(2017$, p. 81$)$

A preocupação em torno das experiências realizadas sobre si, sem seguir protocolos especificados na resolução CNS n 196/96 é alta pois, não se pode olvidar a possibilidade de efeitos colaterais tais como mutação genética desfavorável e alterações no genoma de microrganismos.

No mais, a questão faz refletir sobre os princípios da Bioética, principalmente no que diz respeito à autonomia, beneficência e não-maleficência ao tratar como proprietários do princípio o terceiro a ser estudado, mas não em relação à pesquisa em si, realizada pelo pesquisador no seu próprio corpo. Como descrito já acima, seguir os princípios elencados por Beauchamp e Childress, diz respeito não somente ao poder da pessoa em decidir seu próprio rumo nas questões relacionadas aos tratamentos e submissão às pesquisas de cunho experimental, ou se a mesma causará bem ao ser humano, ou, ainda, não lhe causar dano, mas também em um todo em prol da coletividade, da sociedade como um todo. A situação em que um ser humano se predispõe à ser experimento da sua própria intenção de pesquisa pode colocar à risca a sua obrigação em seguir os ditames éticos, principalmente no que diz respeito à falta do pensar em todos os demais como uma sociedade, coletividade.

Nesse sentido, acredita-se que, mesmo que o corpo submetido à pesquisa seja do próprio pesquisador, ainda que esse desconheça os resultados inerentes mas, mesmo assim, sob a guarda do princípio da autonomia, dispõe-se a ser parte da sua pesquisa, é imprudente não considerar os riscos que tal procedimento possa causar tanto ao seu próprio corpo bem como à sociedade.

\section{CONCLUSÃO}

Com a leitura do texto, pode-se concluir que pesquisas com humanos já eram realizadas muito antes da construção do termo Bioética, que tem por objetivo refletir sobre os questionamentos éticos da vida humana a prevenir tanto problemas atuais como de futuras gerações. O desenvolvimento da ciência, mormente se tratando da área da saúde em relação ao homem, foi realizado com base em características que suprimiam o princípio da dignidade da pessoa humana e é justamente por esse motivo que é válido ressaltar importância do marco teórico referencial da Bioética, onde Beauchamp e Childress elaboraram a lista de quatro princípios limitadores da atuação dentro da forma moral e 
ética, embasando, inclusive, grandes documentos como a Declaração Universal sobre Bioética e Direitos Humanos.

Isso explica a interligação entre Bioética e os Direitos Humanos, principalmente ao que se refere à questão da Bioética se embasar no princípio da dignidade da pessoa humana, grande fundamento dos Direitos Humanos. Ainda, válido mencionar que, quando determinados conhecimentos científicos na área da saúde tem toda a humanidade e suas futuras gerações como extensão dos seus efeitos, é de suma importância d sua normatização por intermédio da Bioética em detrimento das diretrizes adotadas pelos estudos em Direitos Humanos.

Diante do estudo proposto, extrai-se que pesquisar utilizando humanos traz muitos benefícios à sociedade, bem como pode lhes causar certos prejuízos, concluindo-se assim, que as normas jurídicas estabelecidas para regular a pesquisa aplicada em humanos devem seguir os princípios estabelecidos pela Bioética.

Por fim, diante da situação instada, que pesquisas realizadas por biohackers muitas vezes não seguem os protocolos atribuídos à pesquisa envolvendo humanos, quando esses aplicam sobre si substancia capaz de alterar seu DNA, pois, a prática não releva nenhum dos princípios instituídos pela Bioética para evitar danos eventualmente desconhecidos que possam ser estendidos à coletividade, demonstrando fragilidade na lei, tornando necessário o debate do tema.

\section{REFERÊNCIAS}

ANDRADE, Carlos Henrique Vianna de. A Bioética da pesquisa clínica na história. In SILVA, José Vitor da (Org). Bioética: meio ambiente, saúde e pesquisa. $1^{\text {a }}$ edição. São Paulo: Iátria, 2006.

ARAÚJO, Laís Záu Serpa de. Aspectos éticos da pesquisa científica. Revista Pesquisa Odontológica Brasileira, volume 7. São Paulo, maio 2003. Disponível em http://dx.doi.org/10.1590/S1517-74912003000500009 Acesso em: 19 mar 2018. AREND, Marcela Corso; PEREIRA Jessica Olivaes; MARKOSKI, Melissa Medeiros, O Sistema CRISPR/Cas9 e a Possibilidade de Edição Genômica para a Cardiologia. Arq. Bras. Cardiol. ol.108 no.1 São Paulo Jan. 2017, p. 81 - 83. Disponível em http://www.scielo.br/pdf/abc/v108n1/pt_0066-782X-abc-108-01-0081.pdf .Acesso em 08 abr 2018.

BARRETO, Vicente de Paulo, Bioética, biodireito e Direitos Humanos, In: TORRES, Ricardo L. (Org), Teoria dos direitos fundamentais. Rio de Janeiro: Renovar, 1999. p. $383-423$ 
BAZZANO, Félix Carlos Ocáriz Aspectos éticos da pesquisa científica. In SILVA, José Vitor da (Org). Bioética: meio ambiente, saúde e pesquisa. $1^{a}$ edição. São Paulo: Iátria, 2006, p. $149-180$.

BAZZANO, Félix Carlos Ocáriz. SILVA. Aspectos éticos da pesquisa científica. In José Vitor da (Org.). Bioética: meio ambiente, saúde e pesquisa. $1^{\text {a }}$ edição. São Paulo: Iátria, 2006, p. 153-154.

BEAUCHAMP, T.L.; CHILDRESS, J. F. Princípios de ética biomédica. Tradução: Luciana Pudenzi. Edições Loyola, São Paulo: 2002.

BORGES, Gustavo, Bioética aplicada e aspectos jurídicos da prática hospitalar. $1^{\mathrm{a}}$ edição. São Paulo: Multideia, 2017.

BORGES, Gustavo. Erro médico nas cirurgias plásticas. $1^{\text {a }}$ Edição. São Paulo: Editora Atlas S.A., 2014

BRASIL. Código de Ética Médica. Disponível em http://www.portalmedico.org.br/novocodigo/integra.asp Acesso em:19 mar 2018. BRASIL. Constituição da República Federativa do Brasil. Disponível em http://www.planalto.gov.br/ccivil_03/constituicao/constituicao.htm Acesso em:19 mar 2018.

BRASIL. Lei no 10.406, de 10 de janeiro de 2002. Código Civil Brasileiro. Disponível em http://www.planalto.gov.br/CCivil_03/leis/2002/L10406.htm Acesso em: 19 mar 2018. BRASIL. Lei $\mathbf{n}^{\mathbf{0}} \mathbf{n}^{\mathbf{0}}$ 9.434, de 4 de fevereiro de 1997. Disponível em http://www.planalto.gov.br/ccivil_03/Leis/L9434.htm Acesso em: 19 mar 2018.

CLOTET, Joaquim. Bioética - uma aproximação. $1^{\text {a }}$ edição. Porto Alegre: Edipucrs, 2003.

CLOTET, Joaquim. Bioética. In SANTOS, Francisco de Araújo. O impacto das novas tecnologias na sociedade. $1^{\mathrm{a}}$ edição. Porto Alegre. Edipucrs, 2001. p. 41-57.

CLOTET, Joaquim. Por que Bioética, Bioética. Brasília, Conselho Federal de Medicina Volume 1, 1, n. 1. 1993. p. 13 - 19.

COMPARATO, Konder Fábio. A afirmação histórica dos Direitos Humanos. $5^{\text {a }}$ edição. São Paulo: Saraiva, 2007.

DECLARAÇÃO UNIVERSAL DOS DIREITOS HUMANOS. Assembleia Geral das Nações Unidas em Paris. 10 dez. 1948. Disponível em: http://www.dudh.org.br/wpcontent/uploads/2014/12/dudh.pdf Acesso em: 19 mar 2018. DINIZ, Maria Helena. O estado atual do biodireito. São Paulo, Saraiva, 2001.

DRUMOND, José Geralde de Freitas. Bioética clínica e direito médico. Revista Centro Universitário São Camilo - 2012, p. 78 - 89.

ENGELHARDT, H. Tristram. Fundamentos de Bioética. 2. ed. São Paulo: Loyola, 1998. FONTINELE JUNIOR, Klinger. Pesquisa em saúde: ética, Bioética e legislação. $1^{\mathrm{a}}$ edição. Goiania: AB Editora, 2003.

GOLDIM, José Roberto. Bioética complexa. Revista da AMRIGS, Porto Alegre, 53 (1). Jan - Mar 2009. Pag. 58 - 63. Disponível em http://www.ufrgs.br/bioetica/ Acesso em: 19 $\operatorname{mar} 2018$.

GOLDIM, José Roberto. Bioética e espiritualidade. Disponível em https://www.ufrgs.br/bioetica/espirit.htm Acesso em: 19 mar 2018.

GOLDIM, José Roberto. Bioética. Disponível em: http://www.bioetica.ufrgs.br Acesso em:: 19 mar 2018.

GOLDIM, José Roberto. Bioética: origens e complexidade. 2006. Disponível em https://www.ufrgs.br/bioetica/complex.pdf Acesso em: 19 mar 2018.. 
GOLDIM, José Roberto; RAYMUNDO, Marcia Mocellin; DEZORZI, Luciana Winterkorn. Religiões e credos no Brasil: um guia breve para profissionais de saúde/Luciana, Cria Ideais. - Porto Alegre, 2016.

GUZ, Gabriela. Portal da Bioética. Disponível em

http://www.portaldabioetica.com.br/index.html Acesso em: 19 mar 2018.

IBGE - Instituto Brasileiro de Geografia e Estatísticas: Disponível em

http://www.ibge.gov.br/estadosat/temas.php?sigla=sc\&tema=censodemog2010_relig.

Acesso em:: 19 mar 2018.

JUNGES, José Roque. Bioética: perspectivas e desafios. São Leopoldo: Edição

UNISINOS, 1999.

MARTINS-COSTA, Judith. A universidade e a construção do biodireito. Revista de

Direito Sanitário, v. 2, n. 2, julho 2002, p. $61-81$.

MOLLER, Letícia Ludwing, Bioética e Direitos Humanos: delineando um biodireito mínimo universal. Revista Filosofazer. Instituto Superior de Filosofia Berthier. Ano XVI, no 30. Jan - Jun 2007 p. 153 - 172.

OLIVEIRA, Aline Albuquerque S. de. El análisis de la interfase entre la Bioética y los derechos humanos. Revista Latinoamericana de Derechos Humanos. Vol. 22 (1): 89. 103 enero-junio, 2011

OLIVEIRA, Paulo Henrique de; ANJOS FILHO, Roberio Nunes dos. Bioética e pesquisas em seres humanos. Verista da Faculdade de Direito da Universidade de São Paulo v. 101, Janeiro 2006. p. 1187- 1227.

Pessini, Leo. As origens da Bioética: do credo bioético de Potter ao imperativo bioético de Fritz Jahr. Revista Bioética (Impr.). Ano 2013; no 21. p. 9 -19.

RIVABEM, Fernanda Schaefer. Biodireito: uma disciplina autônoma? Revista Bioética, ano 2017, n. 25 (2), p. 282-289.

RODRIGUES, Teresa F. A população portuguesa. Das longas permanências à conquista da modernidade. Revista População e Sociedade CEPESE Porto, vol. 18 2010, p. 21 - 41. RUBIO, David Sanchez. Encantos e desencantos dos Direitos Humanos: de emancipações, libertações e dominações. Tradução de Ivone Fernandes Morcilho Lixa e Helena Henkin. Porto Alegre: Livraria do Advogado, 2014.

SAKAGUTI, Nelson Massanobu; JUNQUEIRA, Cilene Rennó; RAMOS Dalton Luz de Paula RAMOS, Experimentos com seres humanos: fundamentos e normas. In Daniel Luiz de Paula (Org). Bioética: Pessoa e vida. $1^{a}$ edição. São Caetano do Sul: Difusão Editora, 2009, p. $297-309$.

SANTOS, Boaventura de Souza. Introdução a uma ciência pós moderna. 3. ed. Rio de Janeiro: Graal, 1989.

SILVA, Elaine Cristina Camillo da; GOMES, Isabella Mantovani; RAMOS, Daniel Luiz de Paula RAMOS. Princípios da Bioética personalista. In Daniel Luiz de Paula (Org.).

Bioética: Pessoa e vida. 1a edição. São Caetano do Sul: Difusão Editora, 2009.

SILVA, Reinaldo Pereira e. Biodireito: o novo direito da vida. In WOLKMER, Antonio Carlos; LEITE, José Rubens Morato (Org.)., "Os novos” direitos no Brasil: natureza e perspectiva: uma visão básica das novas conflitualidades jurídicas. $3^{\text {a }}$ edição. São Paulo: Saraiva, 2016, p. $261-285$.

SOARES, André Marcelo M.; PIÑEIRO, Walter Esteves. Bioética e biodireito - Uma introdução. $2^{a}$ edição. Rio de Janeiro: Edições Loyola, 2006.

SOUZA, Ricardo Timm de. Bases filosóficas da Bioética e sua categoria fundamental: uma visão contemporânea. In: Bioética. Brasilia, Conselho Federal de Medicina, v. 13, n. 2, 2005, p. $11-30$.

Revista de Biodireito e Direito dos Animais | e-ISSN: 2525-9695 | Salvador | v. 4 | n. 1 | p. 1 - 21 | 
SOUZA, Virgínio Cândido Tosta de; PESSINI, Leo; HOSSNE, William Saad. A medicina tem como finalidade precípua o cuidar de pessoas, e, nesse contexto, a relação médico paciente representa o sentido, o significado, a identidade da profissão médica. Revista Centro Universitário São Camilo - 2012, p. 181-190.

SOUZA, Virgínio, Cândido Tosta de Souza. Bioética, ciência e tecnologia na sociedade contemporânea. In SILVA, José Vitor da (Org.). In Bioética: meio ambiente, saúde e pesquisa. $1^{a}$ edição. São Paulo. Iátria, 2006. p. 25 - 33

TEIXEIRA, F. O potencial libertador da espiritualidade e da experiência religiosa: AMATUZZI, M. M. Psicologia e espiritualidade. São Paulo: Paulus, 2005. p. 13-30. THOMAZI, Tanize Zago. Biotecnologia, biodireito e o futuro da humanidade. Biodireito, direito, constituição e cidadania: contribuições para os objetivos de desenvolvimento do Milênio.CONPEDI, Florianópolis, 2015, pág. 198 - 213. Disponível em https://www.conpedi.org.br/publicacoes/c178h0tg/8v11 nwv1/1wdw8jA184uXW0B9.pdf Acesso em:: 19 mar 2018.

UNESCO. Declaração universal sobre Bioética e Direitos Humanos. Portugal, 2006, Disponível em http://unescdoc.unesco.org/images/0014/001461/146180por.pdf. Acesso em:: 19 mar 2018.

WOLKMER, Antônio Carlos. Introdução aos fundamentos de uma teoria geral dos "novos" direitos.. In WOLKMER, Antonio Carlos; LEITE, José Rubens Morato (Org.). "Os novos" direitos no Brasil: natureza e perspectiva: uma visão básica das novas conflitualidades jurídicas. $3^{\text {a }}$ edição. São Paulo: Saraiva, 2016, p. 17 - 50. 